\title{
Species Diversity and Structure of Wing Scales of Euploea and Papilio Butterflies from Phromlaeng, Nam Nao National Park, Phetchabun Province
}

\author{
Sukhum RUANGCHAI ${ }^{1,4}$, Sirikamon PHLAI-NGAM ${ }^{2}$ and \\ Nisarat TUNGPAIROJWONG ${ }^{2,3, *}$
}

${ }^{1}$ Department of Physics, Faculty of Science, Khon Kaen University, Khon Kaen 40002, Thailand

${ }^{2}$ Department of Biology, Faculty of Science, Khon Kaen University, Khon Kaen 40002, Thailand

${ }^{3}$ Applied Taxonomic Research Center, Khon Kaen University, Khon Kaen 40002, Thailand

${ }^{4}$ Institute of Nanomaterials Research and Innovation for Energy, NANOTEC-KKU RNN on

Nanomaterials Research and Innovation for Energy, Khon Kaen University, Khon Kaen, Thailand 40002

("Corresponding author's e-mail: knisar@kku.ac.th)

Received: 11 June 2017, Revised: 16 February 2018, Accepted: 15 March 2018

\begin{abstract}
This study focuses on species diversity of butterflies in the genera Euploea and Papilio in Nam Nao National Park. The butterflies were investigated every month for one year using insect nets. A total of 11 species, belonging to 2 genera and 2 families, were found. These were E. algea, E. camaralzeman, E. core, E. midamus, E. mulciber, E. radamanthus, E. sylvester, P. helenus, $P$. memnon, $P$. nephelus, and $P$. paris. The structure of the wing scales in different colour areas of 9 species was studied using a stereo microscope and a scanning electron microscope. The general structure of the wing scales of the butterflies of genus Euploea, independent of the colour it produces, is of longitudinal ridges, composed of tilted scutes, cross ribs that connect the ridges, and trabeculae, which link the cross ribs to the membrane of the wing scale's upper lamina. In the Papilio species, there are 2 types of wing scales: one that exhibits bluegreen iridescence and has wide-spaced ridges with concavities in between; and one displaying white, black, yellow, and red and has smaller widths between the ridges, with the space in between them containing a reticular pattern of cross ribs. The study of the wing scale microstructure of the butterflies in the Euploea and Papilio genera indicates that the patterns of the wing scale structure are genus-specific and that, despite showing similar colours, the wing scales are equipped with different mechanisms exemplifying diversity in structural coloration in nature.
\end{abstract}

Keywords: Species diversity, Euploea, Papilio, wing scale, structural colour

\section{Introduction}

Euploea (family Nymphalidae) and Papilio (family Papilionidae) are 2 genera of butterflies in the order Lepidoptera [1]. They play important roles in natural ecosystems as pollinators and as food in the food chain. Many species serve as indicators of environmental health and are a popular motif in the visual and literary arts. Tropical butterfly assemblages are very diverse, with a wide range of endemic species whose distribution is highly dependent on forest types and food plants [2-4].

In Thailand, there are many kinds of tropical rain forests, distributed over several National Parks and Wildlife Sanctuaries. Located in the Central Region's Phetchabun Province and the North-Eastern Region's Chaiyapum Province, Nam Nao National Park is contiguous with Tad Mok National Park and Phu Pha Daeng and Phu Kiew Wildlife Sanctuaries. It has an area of $966 \mathrm{~km}^{2}$ and was designated a national park on $7^{\text {th }}$ October 1953. This national park has a very important function of headwater for 
http://wjst.wu.ac.th

several rivers and creeks. There are many drainage areas in the park, which are vital catchments for river systems including the Yakruea Stream, Phromlaeng Stream, Huai Nam Chen, Loei River, and Pa Sak River. The average annual temperature is $25^{\circ} \mathrm{C}$ and the elevation is $650-1,200 \mathrm{~m}$ above sea level [5]. A typical feature of the fauna in this area is great diversity of butterflies [1,6,7]. However, there have been only a few studies of butterfly species diversity in Nam Nao National Park, with no such reports from Phromlaeng. A previous study reported a total of 323 species of butterflies in the national park, including 9 Euploea and 8 Papilio species [8].

To build on the knowledge of species diversity of earlier works, we have chosen our sampling site in Phromlaeng, where no studies on species diversity of butterflies have been conducted. We have focused on 2 butterfly genera, namely Euploea and Papilio, and selected areas on their wings showing interesting colours for further microscopic study.

Butterfly wings are naturally occurring materials that have long attracted research interests, first by natural scientists and, increasingly, later by material scientists working in the field of bioinspiration. Butterfly wings come in several colours and patterns. The various types of coloration and patterns on the wings serve a number of purposes. The wings have a function in thermoregulation, where they are used to reflect solar radiation to the butterfly's body [9]. Patterns and colours are also used for anti-predatory purposes [10] and play a significant role in mate choice and sexual interaction [11,12]. Furthermore, ultraviolet colours serve intraspecific communication, possibly related to male-male interactions and mate choice by females [13]. The wide range of colours displayed on butterfly wings originate from either chemical (pigmentary) or structural sources, or sometimes a combination of both. Different colours are produced from wing scales, that cover the entire wings of the butterfly. Wing scales are arranged in rows of basal scales and cover scales, with rows of the former located underneath those of the latter, i.e., basal scales are only partially visible. Structural colours are caused by the interaction of light, with microstructures on the wing scales that are in the order of visible wavelengths [14]. Shaped like a dorsoventrally flattened sac, a wing scale is approximately $75 \mu \mathrm{m}$ wide, $200 \mu \mathrm{m}$ long, and $5 \mu \mathrm{m}$ thick [15]. It consists of a lower lamina, which is usually smooth, and an upper lamina bearing intricate microstructures. Terms used to describe different components of the upper lamina vary slightly. The terms to be used throughout this paper are based on the work of Ingram and Parker [16]. Generally, a wing scale contains a series of ridges running along its length. Ridges have dorsal outgrowths called scutes. Located laterally on the ridges are flutes, which may extend to the adjacent ridges forming cross ribs. All of these structures are connected to the membrane of the upper lamina by vertical supports called trabeculae. The space between the trabeculae is termed lumen.

In pigmentary coloration, pigments like melanin [17] or fluorescent pigments [18] are integrated into the chitinous structure of the scale. Only in the Pieridae [19] are pigment granules observed in the lumen. In structural coloration, 3 types of photonic structures have been identified: diffraction gratings, multilayer reflectors, and photonic crystals [16]. So far, several materials based on the design of the architecture of the wing scale producing structural colour have been fabricated [20-23].

The objectives of the study were to reveal the species diversity of Euploea and Papilio butterflies from Phromlaeng, Nam Nao National Park, and to determine the microstructures of the wing scales producing different colours in each species of Euploea and Papilio using scanning electron microscopy. The results show unity in structures, independent of the colour produced, in wing scales of the Euploea species, and different structural patterns when blue, as opposed to white, black, yellow, or red, is produced from the wing scales of the Papilio species.

\section{Materials and methods}

Study site

The study site is Phromlaeng (Figure 1) located in the Nam Nao National Park, Thailand (latitude: $16^{\circ} 38^{\prime} 24.02^{\prime \prime} \mathrm{N}$ and longitude: 101 $\left.{ }^{\circ} 34^{\prime} 52.9^{\prime \prime} \mathrm{E}\right)$. The dry evergreen forest of Phromlaeng has an elevation of $740 \mathrm{~m}$ above sea level. It has a small check dam constituting a small barrier built across the direction of the water flow of the Phromlaeng Stream. 
http://wjst.wu.ac.th

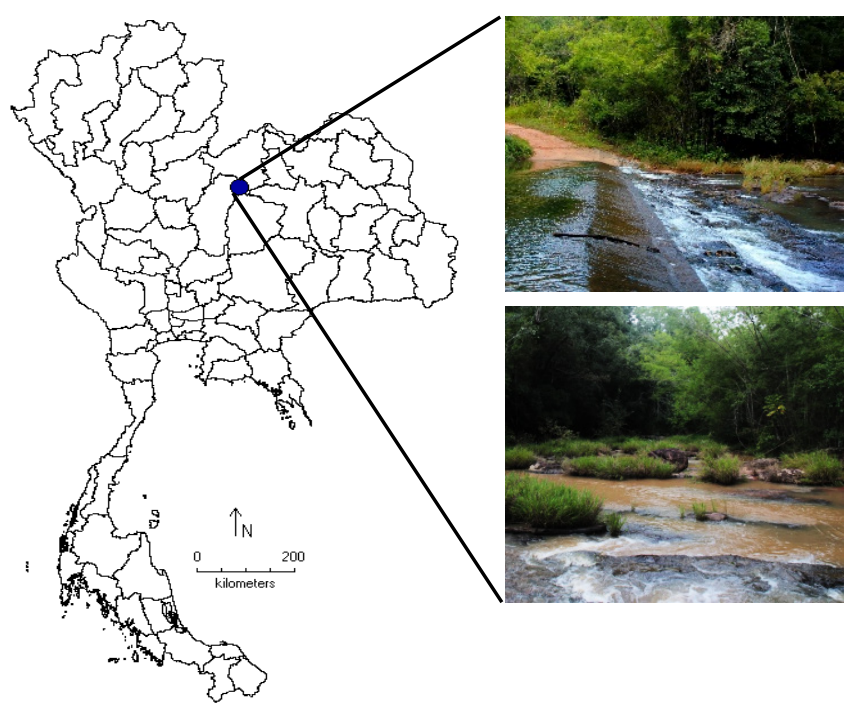

Figure 1 Study site for the butterflies' fauna study from Phromlaeng, Nam Nao National Park

\section{Sampling and identification}

Field surveys for butterflies were conducted monthly from May 2016 to April 2017. The butterfly samples were collected by hand nets from 8.00 a.m. to 3.00 p.m. Attempts were made to catch every butterfly, but only the diversity of the 2 butterfly families of Nymphalidae and Papilionidae is presented here. The external morphology keys of Ek-Amnuay [1], Pinratana [24], and Suwanpak [25] were used for identification.

\section{Scanning electron microscopy}

Different areas on the wing scales of butterflies of the 2 families collected from our surveys were subjected to scanning electron microscopy. We coated the specimens with $20 \mathrm{~nm}$ of gold and used a Zeiss LEO $1450 \mathrm{VP}$ to image the wing scale microstructures.

\section{Results and discussion}

\section{Diversity of butterfly}

Qualitative sampling of butterflies from Phromlaeng of Nam Nao National Park was taken monthly during May 2016 to April 2017. A total of 11 species collected by hand nets could be classified into 2 families and 2 genera (Euploea and Papilio). The species belong to either the family Nymphalidae (Subfamily Danainae) or the family Papilionidae (Subfamily Papilioninae). There were 7 species of the genus Euploea (Figure 2) and 4 species of the genus Papilio (Figure 3). Table 1 shows a species list of the butterflies found in Phromlaeng. The butterfly families of Nymphalidae and Papilionidae are large groups of Lepidoptera, and include many common species, which can be found in a wide range of habitats. Comparatively, Euploea was the most dominant genus, having the highest number of species, at 7 species. For the present study, the species richness of butterflies was recorded during the summer season. On the basis of the total number of species recorded, Euploea species were the most frequently found at the site, because they often fly through canopy openness and sunshine. Another butterfly genus, Papilio, was rarely found, and only a few were found at the site of the survey. Our results were compared with those reported by Chondamrongkul and Chamnankid [8], who studied butterflies from 5 forest types at Chern watershed area, Nam Nao National Park. They also found butterflies of the family Nymphalidae 
(9 species) and Papilionidae (8 species). Almost all species of the genera Euploea and Papilio found in our study were recorded in Chondamrongkul and Chamnankid [8], except Euploea midamus. This species was newly recorded in the dry evergreen forest from Phromlaeng, and was only found in May, which may be due to food sources and natural habitats of butterflies [3]. From our observation, the butterfly populations increased during the period of high temperatures, low precipitation, and light penetration, in agreement with the study of Boonvanno et al. [2]. Furthermore, the area around the sampling site had experienced a change through the construction of small dams, which replaced or reduced natural habitats and wild plants that provide nectaring and egg-laying for the butterflies. This will likely have had a great impact on the butterfly population and species richness.

Table 1 Species list of Euploea and Papilio at Phromlaeng, Nam Nao National Park

\begin{tabular}{ll}
\hline \multicolumn{1}{c}{ Genus Euploea } & Genus Papilio \\
\hline Euploea algea & Papilio helenus \\
Euploea camaralzeman & Papilio memnon \\
Euploea core & Papilio nephelus \\
Euploea midamus & Papilio paris \\
Euploea mulciber & \\
Euploea radamanthus & \\
Euploea sylvester & \\
\hline
\end{tabular}

\section{Genus Euploea Fabricius, 1807}

Euploea butterflies are in the family Nymphalidae and the subfamily Danainae. Members of Euploea are usually characterized by dark or dark-brown wings with blue gloss. The blue gloss may be present in the forewing or hindwing or both [24]. Seven species of the Euploea butterflies were found in our survey in Phromlaeng. The description of their characteristics is as follows [1,24,25];

\section{Euploea mulciber Cramer (Figure 2.1)}

Male. Upperside: forewing with a bright blue gloss and marked with submarginal and postdiscal series of white and blue spots; also, one spot in the cell and another discal spot at or beyond the apex of the cell. Hindwing with a large velvety brown patch on the posterior half dividing the wing diagonally. Underside: similar to upperside, with clearer markings but with a uniform brown colour without blue gloss. Female. Upperside: forewing blue gloss only in the discal region. The white spots of the forewing clearer and larger; basal streaks, one of which passes through the cell. On the hindwing, a series of basal streaks, one followed by other streaks extending from the discal to the postdiscal region, and submarginal white spots. Underside: similar to the upperside.

\section{Euploea camaralzeman Butler (Figure 2.2)}

Male. Upperside: forewing dorsum convex; basal and discal part of the forewing glossy blue; one discal spot, one or a few postdiscal spots, and few submarginal tiny spots. On the hindwing, blue gloss over the posterior basal and distal regions, and postdiscal and submarginal spots. Underside: similar to upperside, but sometimes with a few more additional spots of lighter brown. Female. Forewing with a few more spots, and hindwing with white spots at the apex of the cell, one or more discal spots, and postdiscal and submarginal spots similar to the male, but larger. 


\section{Euploea radamanthus Fabricius (Figure 2.3)}

Male. Upperside: forewing short with blue gloss; a submarginal series of blue spots; apical part of cell filled with white patch; white spot at the apical angle of the cell exteriorly in space 3 and midcostal white streak above the cell; short blue band in $1 \mathrm{~b}$. Hindwing with broad white streaks in space 1a-2, marginal and submarginal blue spots incomplete. Underside: light brown. Forewing similar to upperside, but with an additional discal white spot. Hindwing similar to upperside, but with more streaks. Female. Upperside: forewing with irregular white spots made up of patches from the apex of the cell to midcosta; a white spot beyond the cell in space 3 and 2 spots in space 2 . Hindwing with streaks in the cell, not found in the male. Underside: similar to upperside.

\section{Euploea sylvester Fabricius (Figure 2.4)}

Male. Upperside: forewing glossed with blue and with a bright submarginal series of blue spots and incomplete and obscure series of marginal spots of the same hue; 2 parallel bands in space 1. On the velvety hindwing, no blue gloss, except in the discal region; a submarginal and a post discal series of white spots. Underside: brownish dark. On the forewing, an apical spot in the cell, and bluish discal spots in spaces 2, 3, and 6, as also postdiscal and submarginal series of spots. Hindwing with the above marks, as well as the marks on the upperside. Female. Similar to the male, but larger.

\section{Euploea algea Godart (Figure 2.5)}

Male. Upperside: on the glossy blue forewing, a prominent brand in space $1 \mathrm{~b}$; post discal and submarginal spots incomplete and obscure. On the hindwing, the spots clearer and more complete. Underside: velvety brown. On the forewing, post discal and submarginal dots clearer, but incomplete, discal spots in spaces 2 and 3, apical cellular spot; also, one more spot beyond the apex of the cell on the costa. On the hindwing, complete and clear series of post discal spots; a spot in the cell space and, on its periphery, a series of pinkish spots from spaces 2 - 6. Female. Similar to the male, but the brand on forewing represented only by a trace on the upperside.

\section{Euploea core Cramer (Figure 2.6)}

Male. Upperside: pale along the margin of the wing, especially the forewing. Forewing with postdiscal and submarginal series of spots that are absolescent, its apical region dusted with bluish white. Hindwing with submarginal series of spots and postdiscal series of oval spots. Underside: paler, but apex of blue forewing not bluish; 2 or 3 discal spots, and apical spot in cell. On the hindwing, with 5 discal spots; otherwise similar to upperside. Female. Similar to the male.

\section{Euploea midamus Linnaeus (Figure 2.7)}

Male. Upperside: forewing suffused with blue, especially at the basal and discal regions; submarginal of spots few of which are visible, and a thin brand in space $1 \mathrm{~b}$ close to vein 2. Hindwing; a series of oval postdiscal spots, and another series of submarginal spots, clear. The blue visible only discally. Female. Similar to the male.

\section{Genus Papilio Linnaeus, 1758}

Papilio butterflies are in the family Papilionidae and the subfamily Palilioninae. Most have swallowtail, but some are tailless. Most Papilio butterflies are large, black and yellow or green, with stout bodies known as birdwings. Several species are very common throughout the country, yet some are difficult to catch alive, as they are located on hills and flit away to great heights when threatened [24]. Four species of Papilio butterflies were found in this survey in Phromlaeng. The description of their characteristics is as follows:

\section{Papilio paris Linnaeus (Figure 3.1)}

Male. Upperside: body and wing green dusted; forewing dark, and darker towards the base. Hindwing with a large patch of bluish green covering spaces 4 - 6 distally, and a red incomplete ocellus at 
space 7, and another at the tornus. Underside: brownish-black; on the forewing, ashy vein-stripes very broad distally. On the hindwing, with a complete series of red submarginal lunules which, in spaces 1 - 3, look more like ocelli-Spatulate tails. Female. Similar to the male.

\section{Papilio memnon Linnaeus (Figure 3.2)}

Male is tailless. Female is polymorphic with tail.

Male. Upperside: black and greenish or bluish vein stripes on both wings.

Underside: black, but with a large red basal spot, which in the hindwing divided by the black veins, and fine long white parallel stripes in spaces 1 - 5 radiating from the periphery of the cell; also, a submarginal series of round spots. Female. f. distantianus Rothchild. Upperside: forewing, with the basal area of the cell red, and the basal area below the cell black. On the hindwings, with white stripes in spaces 1 - 6 converging to the basal part. The stripe in space 6 very faint; submarginal black spots; those in spaces 1 to 3 surrounded by red.

\section{Papilio helenus Linnaeus (Figure 3.3)}

Male. Upperside: the black forewing with 4 thread-like lines in the cell and faint grey vein stripes, which in some cases may look greenish, and in others brownish. The tailed hindwing carries a discal white spot each in spaces 5, 6, and 7, the last nearly quadrate and smaller than the others; also, red marginal rings enclosing black spots from spaces 1 to 5 , the tornal one being very clear and distinct. Underside: a dull black, with clearer vein stripes on the forewing than on the upperside. On the hindwing, the white spots similar to the upperside, the marginal red rings circling the black extending from spaces 5 - 7, the red may look like lunules; also, an additional submarginal red ring in space 2. Female. Similar to the male.

\section{Papilio nephelus Boisduval (Figure 3.4)}

Male. Upperside: forewings are completely black, without any trace of white. The hindwing is velvety black, with a patch of white covering the discal region in spaces 5,6 , and 7 . Underside: black forewing with clear vein stripes, especially towards the margin. Hindwing costal region above the cell with dusted; 3 white patches as on the upperside, black ocellus surrounded by brick red in space 1 and submarginally in space 2; submarginal lunules of brick red enclosing black, traces of white marginally. Female. Similar to the male. 


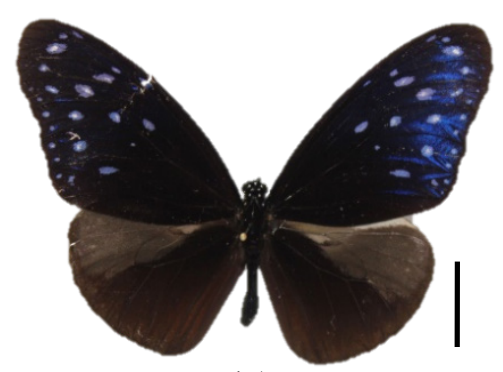

$1 \mathrm{~A}$

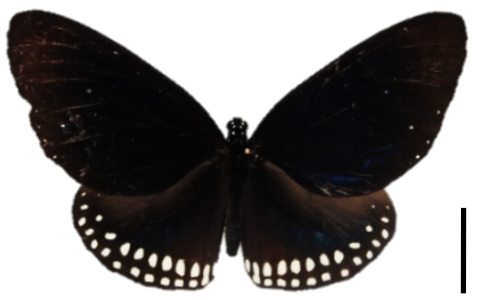

2A

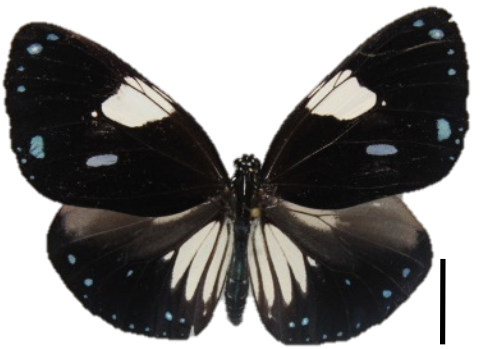

3A

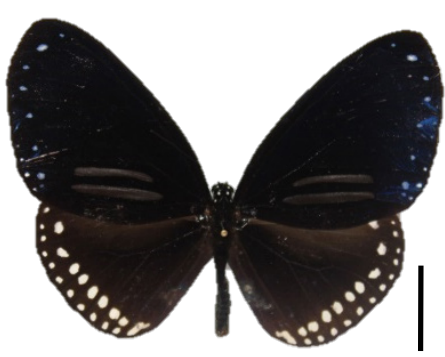

4A

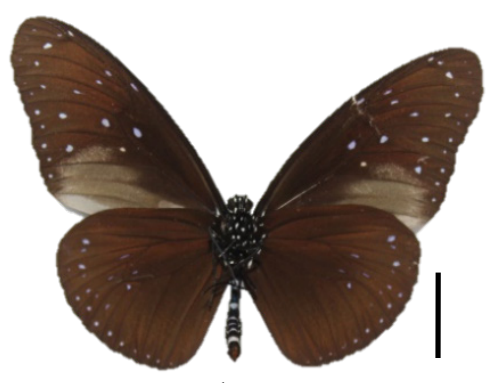

1B

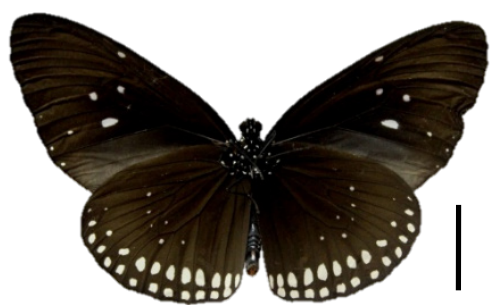

2B

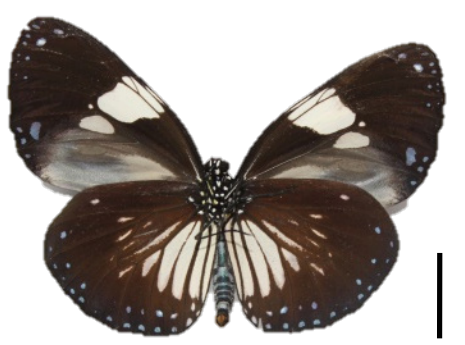

3B

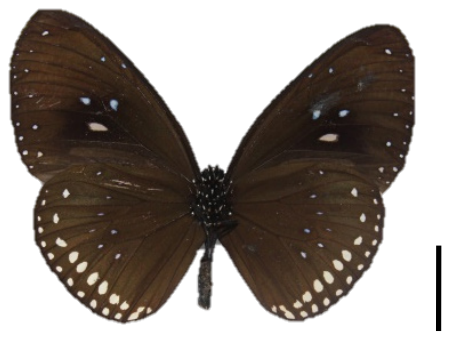

4B 


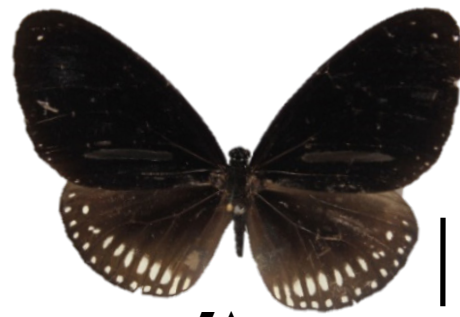

5A

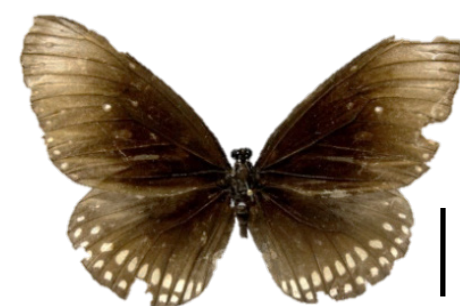

6A

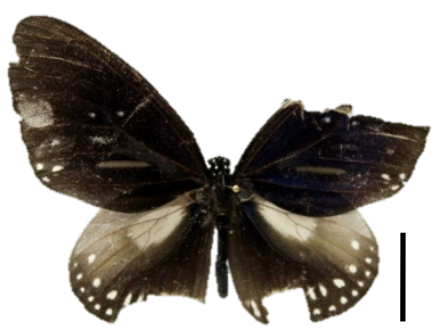

7A

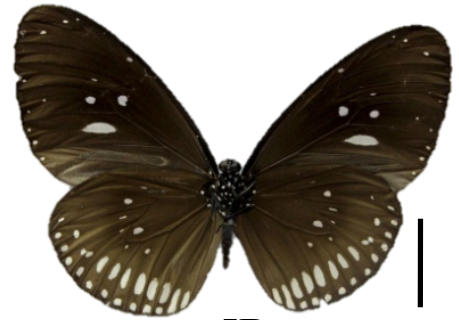

5B

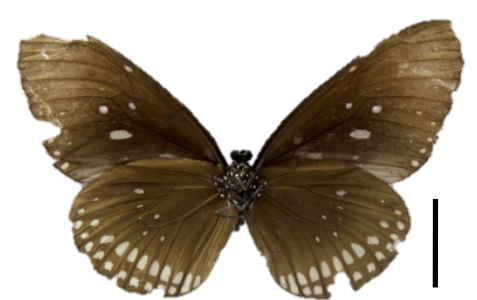

6B

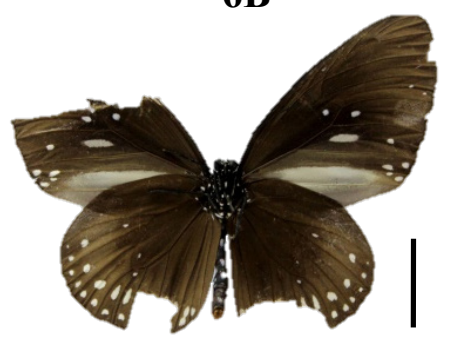

$7 B$

Figure 2 Specimens of the genus Euploea. 1, E. mulciber (A, upperside, B, underside), 2, E. camaralzeman (A, upperside, B, underside), 3, E. radamanthus (A, upperside, B, underside), 4, E. sylvester (A, upperside, $\mathrm{B}$, underside), 5, E. algea (A, upperside, B, underside), 6, E. core (A, upperside, $\mathrm{B}$, underside), 7, E. midamus (A, upperside, B, underside) (scale bar $=2 \mathrm{~cm}$ ). 

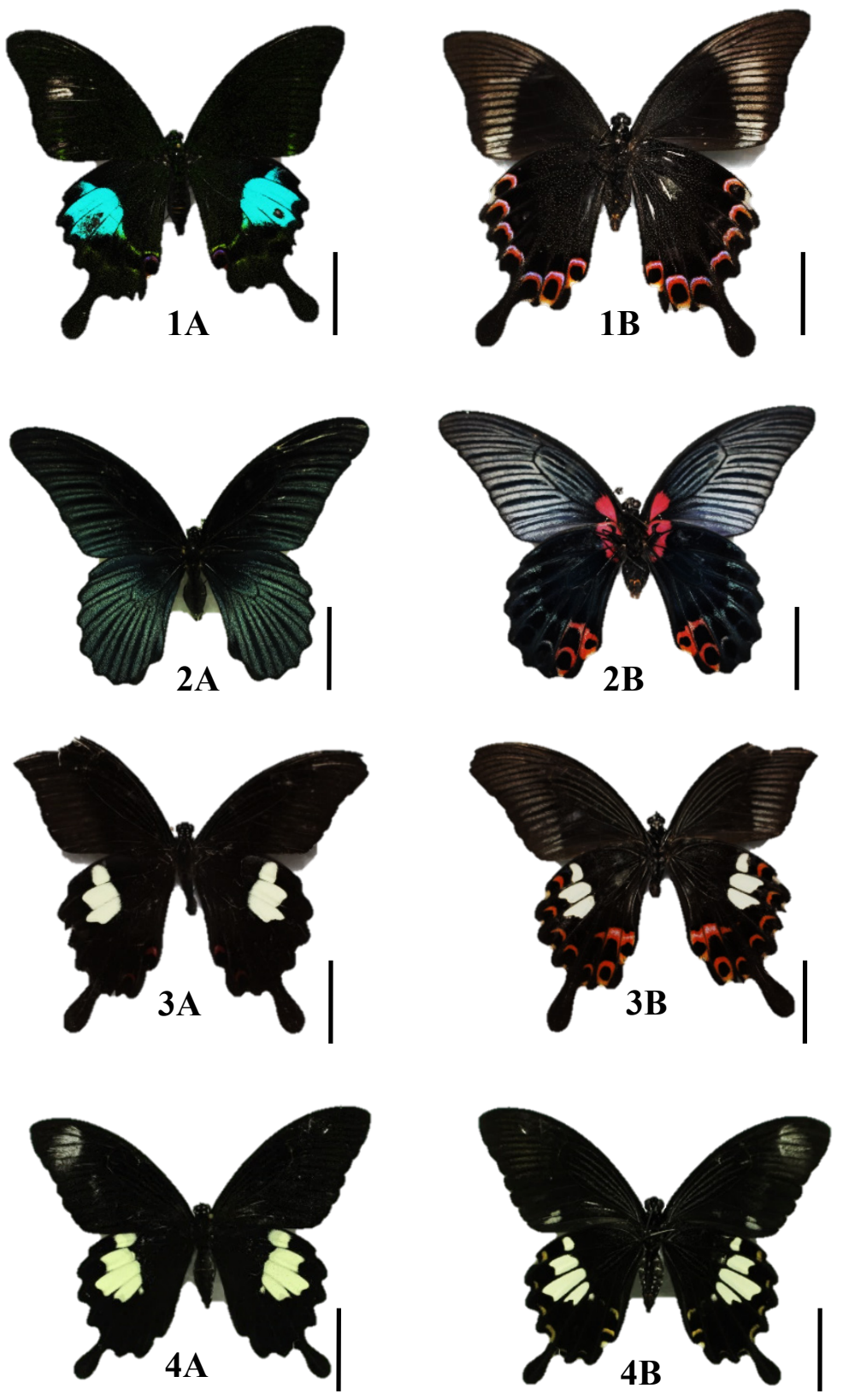

Figure 3 Specimens of the genus Papilio. 1, P. paris (A, upperside, B, underside), 2, P. memnon (A, upperside, $\mathrm{B}$, underside), 3, P. helenus (A, upperside, $\mathrm{B}$, underside), 4, P. nephelus (A, upperside, $\mathrm{B}$, underside) (scale bar $=3 \mathrm{~cm}$ ). 


\section{Structure of wing scales}

Microscopic structures of wing scales from 3 areas of blue iridescence in 3 Euploea species are presented (Figure 4), and those from 2 areas of blue and green iridescence and one displaying red colour in P. paris are shown (Figure 5). In E. mulciber (Figure 4A), basal and cover scales are of similar length; whereas, in E. camaralzeman (Figure 4C) and E. sylvester (Figure 4E), the cover scales are longer than the basal scales. Rows of scales in E. mulciber (Figure 4A) do not overlap, exposing the base of the scales. In E. camaralzeman (Figure 4C) and E. sylvester (Figure 4E), the anterior bases of the scales are hidden from view by the posterior ends of the immediate anterior scales. The architecture of the upper lamina of the 3 Euploea species are comparable (Figure 4B for E. mulciber, Figure 4D for $E$. camaralzeman, and Figure 4F for E. sylvester). A series of ridges run along the length of the scales, with each ridge composed of tilted scutes. Cross ribs laterally link the ridges together, and trabeculae extend from the cross ribs connecting them with the upper lamina membrane (Figures 4B, 4D and 4E). In all species, the spacing between the ridges is about $1 \mu \mathrm{m}$, that between the cross ribs varies slightly, at 400 $600 \mathrm{~nm}$ for E. mulciber and E. camaralzeman, and $600-800 \mathrm{~nm}$ for E. sylvester.

The general architecture of the scales of the Euploea species collected from Phromlaeng is of an unspecialised type [15], with layers of scutes constituting ridges, connected laterally by cross ribs, in turn linked to the upper lamina membrane by trabeculae. The scales of other areas on the wing that display other colours than blue (not shown) also possess an architecture of this type, indicating a general unspecialised pattern of wing scales in Euploea. The iridescent blue shades of E. mulciber have been a subject of detailed study by Dechkrong et al. [26] and Mika et al. [27]. They have found that the highly tilted scutes of the ridges "produce a limited-view, selective wavelength (ultraviolet (UV) green) as a result of multiple interference between the cuticle-air layers" [27]. Factors that affect the iridescence of the scales include refractive indexes of chitin and air, the thickness of the scutes, the spacing between them, and their tilt angle [26,27].

Wing scales of Papilio species are classified into 2 types. The scales exhibiting blue-green iridescence (Figure 5A - 5D) have wide-spaced ridges, with spacing of $8-9 \mu \mathrm{m}$. Between the ridges are dense lines that are about $100 \mathrm{~nm}$ apart. Longitudinally, the space between the ridges are divided in 2 halves, each of which contains structures resembling cross ribs that create several shallow concaves between them. The other type, which displays colours like black, white, yellow, and red (Figures 5E and 5F), have narrower-spaced ridges. The spaces between the ridges are called windows, which have a reticular pattern known as a quasi-honeycomb structure [15]. In green wing scales of $P$. palinurus, having a similar structure to those of the green-blue scales of $P$. paris, the green colour observed by our eyes is actually a result of colour-mixing between yellow from the flat region and blue from the inclined sides of the concavities [28]. Similarly, the blue colour of $P$. ulysses is a mixture of green from the concavities and deep purple from the ridges, in $P$. blumei, the yellow colour from the flat region is mixed with the blue colour from the inclined sides to give the green colour seen by our eyes [29]. From the structural similarity perspective, it is possible that a similar colour-mixing mechanism also occurs in the blue-green scales of $P$. paris. Recently, there have been attempts to manufacture functional materials inspired by the intricate morphology of butterfly wing scales. So-called butterfly fibres are an innovative material, composed of alternately arranged layers of polyester and nylon whose lamina thickness is strictly controlled in order that the colours of the fibres are structural rather than chemical [30]. This health- and environmentally friendly innovation could be a great alternative to the use of synthetic dyes, many of which are toxic and polluting [30]. For potential applications in the fields of security labelling or the manufacture of dynamic and vivid paints and coatings, photonic structures mimicking the wing scale morphology of the Indonesian butterfly Papilio blumei have been fabricated [31]. Based on the design of wing scales of the butterfly Euploea mulciber, 3-dimensional metallic microstructures have been fabricated which could be used in such diverse fields because of their optical, electronic, magnetic, thermal, and catalytic properties [32]. Wing scales of the Morpho butterfly with a coating of gold by way of physical deposition changes the surface morphology of the wing scales, enabling a sensitive optical readout for high-resolution IR detection [33]. The fabrication of these structures exemplifies the diversity of functional materials that could be generated based on the design of wing scale microarchitecture. By exploring the chitinous microstructure of different types of wing scales and relating it to its function, one 
adds new dimensions to the ever-expanding body of knowledge in the field of biological materials, in the hope that interesting design ideas would be picked up by material scientists and engineers alike, who are increasingly looking towards nature for inspiration in the fabrication of new and innovative materials.
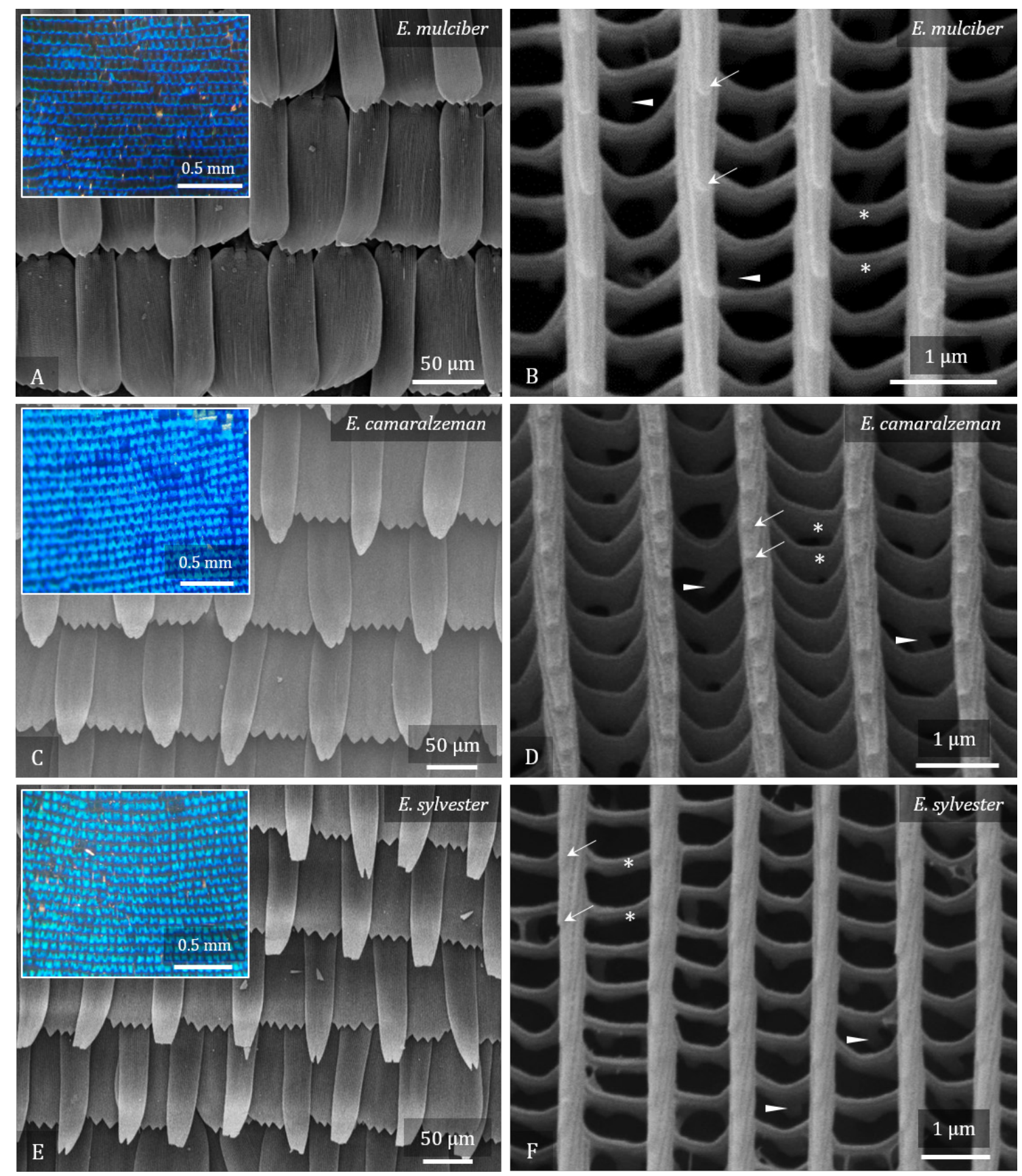

Figure 4 Micrographs and photographs (insets) of wing scales that show blue iridescence in E. mulciber (A and B), E. camaralzeman (C and D), and E. sylvester (E and F). A, C, and E are overviews of the basal and cover scales. B, D, and F show microstructures of the cover scales of the respective species. Arrows mark scutes of the ridges, asterisks cross ribs, and arrowheads trabeculae. 

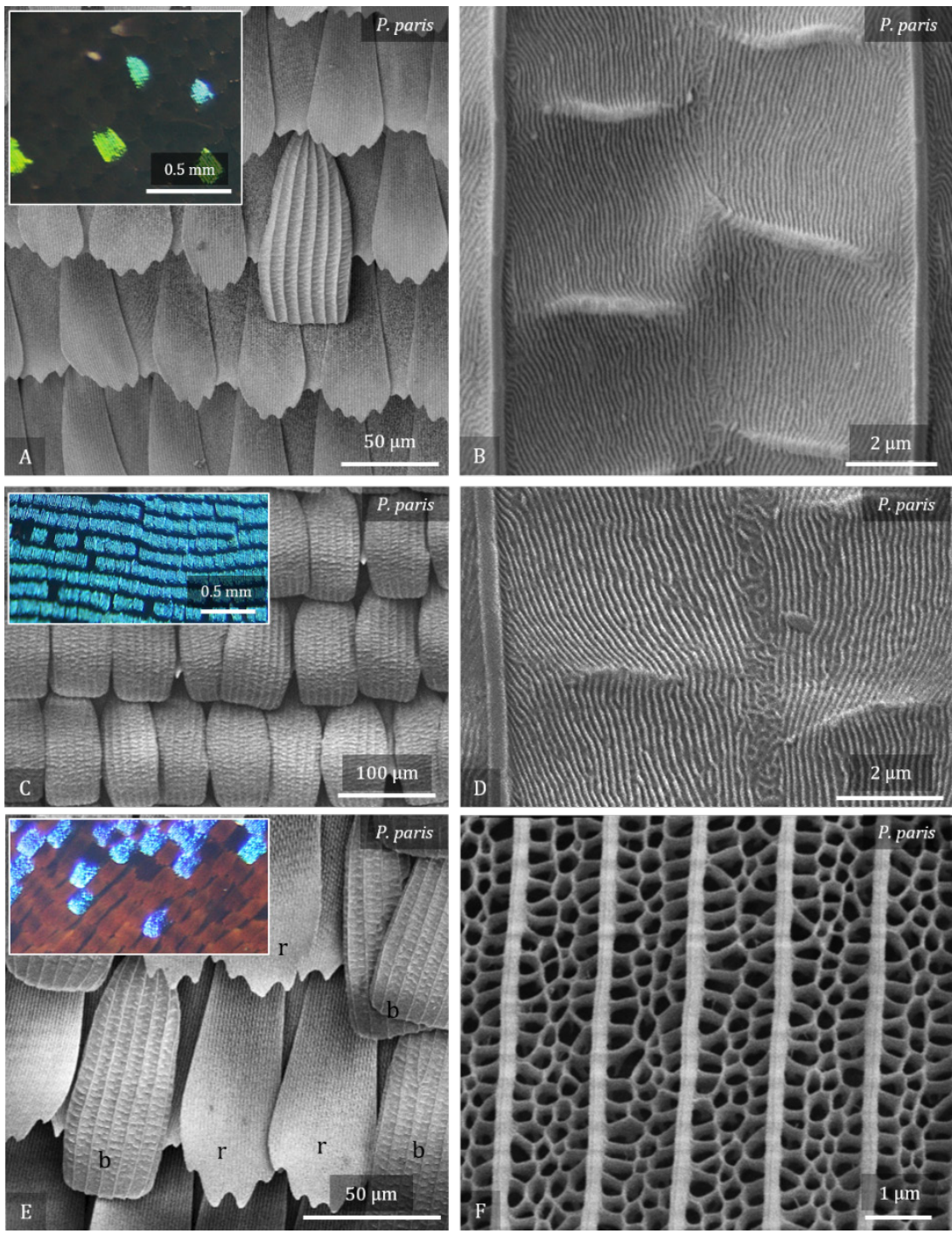

Figure 5 Micrographs and photographs (insets) of wing scales that display blue-green iridescence (A-D) and red colour (E and F) in P. paris. A, C, and E are overviews of the basal and cover scales. B, D, and F show microstructures of the interested scales within the respective parts. A and B: The blue-green scale is distinct from the surrounding black scales by their wider-spaced ridges. In between the ridges, structures resembling concavities are found. $\mathrm{C}$ and $\mathrm{D}$ : The bright blue scales which show a similar architecture to that observed in A and B. E and F: Red (r) and blue (b) scales lie close together, but are structurally distinct. The spaces between the red scales are reticular (a quasi-honeycomb structure).

\section{Conclusions}

A total of 11 species of the genus Euploea and Papilio were found from our collection site in the Phromlaeng of the Nam Nao National Park in Thailand. Three types of wing scales were found from the 2 genera. Wing scales of the Euploea species are similarly constructed, independent of the colour they produce. Each scale is composed of longitudinal ridges, formed by tilted scutes. Lateral cross ribs connect the ridges together, while trabeculae extend from the cross ribs to the membrane of the upper lamina supporting the overall structure of the wing scale. In Papilio, the scales that exhibit blue-green iridescence 
have concavities in between the ridges, whereas those displaying other colours, like white, black, yellow, and red, have a reticular pattern, resembling a quasi-honeycomb structure. Our results are in agreement with previous studies that show genus-specificity of the microstructures found on wing scales. For our future work, we plan to subject wing scales to transmission electron microscopy and to optical experiments, to learn if specific mechanisms are at play in structural coloration of these species.

\section{Acknowledgements}

We thank all the rangers from the Nam Nao National Park for guiding, helping, and ensuring the safety of our research team during the field survey. This research was supported by Khon Kaen University Research Grant 2017 (600062) and was partially supported by the Research Network NANOTEC (RNN) program of the National Nanotechnology Center (NANOTEC), NSTDA, Ministry of Higher Education, Science, Research and Innovation and Khon Kaen University, Thailand.

\section{References}

[1] P Ek-Amnuay. Butterflies of Thailand. $2^{\text {nd }}$ eds. Ammarin Printing and Publishing, Bangkok, 2012, p. $60-218$.

[2] K Boonvanno, S Watanasit and S Permkam. Butterfly diversity at Ton Nga-Chang Wildlife Sanctuary, Songkhla Province, Southern Thailand. J. Sci. Soc. Thailand 2000; 26, 105-10.

[3] J Ghazoul. Impact of logging on the richness and diversity of forest butterflies in a tropical dry forest in Thailand. Biodivers. Conserv. 2002; 1, 521-41.

[4] S Okamoto, M Tomita, C Choosai and Y Hanboonsong. A study on geographical distribution of Papilionidae in Thailand. Evol. Sci. 2013; 18, 29-42.

[5] National Park, Wildlife and Plant Conservation Department, Available at: http://www.dnp.go.th, accessed May 2017.

[6] TW Pyrcz. Butterflies and conservation in the national parks of Thailand. Trop. Lepidop. 1994; 2, $77-82$.

[7] P Ratiwiriyapong. 2004, Diversity of Butterfly Populations at Pha Kluai Mai-Haew Suwat Waterfall Trail, Khao Yai National Park, Thailand, Master Degree Thesis. Mahidol University, Bangkok.

[8] S Chondamrongkul and C Chamnankid. Using butterflies as indicator of biodiversity of Nam Nao National Park. Suranaree J. Sci. Tech.1998; 5, 147-61.

[9] JG Kingslover. Thermoregulatory significance of wing melanization in Pieris butterflies (Lepidoptera: Pieridae): Physics, posture, and pattern. Oecologia 1985; 66, 546-53.

[10] A Lyytinen, PM Brakefield and J Mappes. Significance of butterfly eyespots as an anti-predator device in ground-based and aerial attacks. Oikos 2003; 100, 373-9.

[11] JA Fordyce, CC Nice, ML Forister and AM Shapiro. The significance of wing pattern diversity in the Lycaenidae: Mate discrimination by two recently diverged species. J. Evol. Biol. 2002; 15, 8719.

[12] DJ Kemp and RL Rutowski. The role of coloration in mate choice and sexual interactions in butterflies. Adv. Stud. Behav. 2011; 43, 55-92.

[13] CFA Brunton and MEN Majerus. Ultraviolet colours in butterflies: Intra- or inter-specific communication? Proc. R. Soc. Lond. Ser. B Biol. Sci. 1995; 260, 199-204.

[14] AR Parker. Invertebrate Structural Colours In: E Savazzi (ed.). Functional Morphology of the Invertebrate Skeleton. Wiley, London, 1999, p. 65-90.

[15] D Zhang, W Zhang, J Gu, T Fan, Q Liu, H Su and S Zhu. Inspiration from butterfly and moth wing scales: characterization, modelling and fabrication. Prog. Mater. Sci. 2015; 68, 67-96.

[16] AL Ingram and AR Parker. A review of the diversity and evolution of photonic structures in butterflies, incorporating the work of John Huxley (The Natural History Museum, London from 1961 to 1990). Philos. Trans. R. Soc. Lond. B Biol. Sci. 2008; 1502, 2465-80.

[17] H Ghiradella and W Radigan. Development of butterfly scales. II struts, lattices and surface tension. J. Morphol. 1976; 150, 279-98. 
[18] P Vukusic and I Hooper. Directionally controlled fluorescence emission in butterflies. Science 2005; 310, 1151.

[19] DG Stavenga, S Stowe, K Siebke, J Zeil and K Arikawa. Butterfly wing colours: Scale beads make white pierid wings brighter. Proc. R. Soc. B. 2004; 271, 1577-84.

[20] J Huang, X Wang and ZL Wang. Controlled replication of butterfly wings for achieving tunable photonic properties. Nano Lett. 2006; 10, 2325-31.

[21] W Zhang, D Zhang, T Fan, J Ding, J Gu, Q Guo and H Ogawa. Biosynthesis of cathodoluminescent zinc oxide replicas using butterfly (Papilio paris) wing scales as templates. Mat. Sci. Eng. C Mater. 2009; 29, 92-6

[22] M Crne, V Sharma, J Blair, JO Park, CJ Summers and M Srinivasarao. Biomimicry of optical microstructures of Papilio palinurus. Europhys. Lett. 2011; 93, 14001.

[23] S Zhang and Y Chen. Nanofabrication and coloration study of artificial Morpho butterfly wings with aligned lamellae layers. Sci. Rep. UK. 2015; 16637, 1-10.

[24] A Pinratana. Butterflies in Thailand Volume One. The Viratham Press, Thailand, 1997, p. 92.

[25] K Suwanpak. Butterflies Guide. Sarakadee Press, Bangkok, 2013, p. 91-302.

[26] P Dechkrong, S Jiwajinda, P Dokchan, M Kongtungmon, N Chomsaeng, T Chairuangsri, CC Yu, $\mathrm{CN}$ Hsiao and M Shiojiri. Fine structure of wing scales of butterflies, Euploea mulciber and Troides aeacus. J. Struct. Biol. 2011; 176, 75-82.

[27] F Mika, J Matějková-Plšková, S Jiwajinda, P Dechkrong and M Shiojiri. Photonic crystal structure and coloration of wing Scales of butterflies exhibiting selective wavelength iridescence. Materials 2012; 5, 754-71.

[28] P Vukusic, JR Sambles and CR Lawrence. Colour mixing in wing scales of a butterfly. Nature. 2000; 404, 457.

[29] YY Diao and XY Liu. Mysterious coloring: structural origin of color mixing for two breeds of Papilio butterflies. Opt. Express 2011; 10, 9232-41.

[30] V Rossbach, P Patanathabutr and J Wichitwechkarn. Copying and manipulating nature: Innovation for textile materials. Fiber Polym. 2003; 4, 8-14.

[31] M Kolle, PM Salgard-Cunha, MRJ Scherer, F Huang, P Vukusic, S Mahajan, JJ Baumberg and U Steiner. Mimicking the colourful wing scale structure of the Papilio blumei butterfly. Nature Nanotechnol. 2010; 5, 511-5.

[32] Y Tan, J Gu, X Zang, W Xu, K Shi, L Xu and D Zhang. Versatile fabrication of intact threedimensional metallic butterfly wing scales with hierarchical sub-micrometer structures. Angew. Chem. Int. Edit. 2011; 50, 8307-11.

[33] F Zhang, Q Shen, X Shi, S Li, W Wang, Z Luo, G He, P Zhang, P Tao, C Song, W Zhang, D Zhang, $\mathrm{T}$ Deng and $\mathrm{W}$ Shang. Infrared detection based on localized modification of Morpho butterfly wings. Adv. Mater. 2015; 27, 1077-82. 